\title{
Low prevalence of glucokinase gene mutations in gestational diabetic patients with good glycemic control
}

\author{
H.R. Frigeri ${ }^{1,2}$, I.C.R. Santos ${ }^{1}$, R.R. Réa ${ }^{3}$, A.C.R. Almeida ${ }^{3}$, \\ C.M.T. Fadel-Picheth ${ }^{1}$, F.O. Pedrosa ${ }^{4}$, E.M. Souza ${ }^{4}$, F.G.M. Rego ${ }^{1}$ \\ and G. Picheth ${ }^{1}$ \\ ${ }^{1}$ Programa de Pós-Graduação em Ciências Farmacêuticas, \\ Universidade Federal do Paraná, Curitiba, PR, Brasil \\ ${ }^{2}$ Escola de Saúde e Biociências, Pontifícia Universidade Católica do Paraná, \\ Curitiba, PR, Brasil \\ ${ }^{3}$ Serviço de Endocrinologia e Metabologia do Paraná, Hospital de Clínicas, \\ Curitiba, PR, Brasil \\ ${ }^{4}$ Departamento de Bioquímica e Biologia Molecular, \\ Universidade Federal do Paraná, Curitiba, PR, Brasil \\ Corresponding author: G. Picheth \\ E-mail: gpicheth@ufpr.br
}

Genet. Mol. Res. 11 (2): 1433-1441 (2012)

Received August 19, 2011

Accepted January 24, 2012

Published May 18, 2012

DOI http://dx.doi.org/10.4238/2012.May.18.2

\begin{abstract}
Glucokinase (GCK) plays a key role in glucose homeostasis. Gestational diabetes mellitus increases the risk of gestational complications in pregnant women and fetuses. We screened for mutations in coding and flanking regions of the $G C K$ gene in pregnant women with or without gestational diabetes in a Brazilian population. A sample of 200 pregnant women classified as healthy (control, $\mathrm{N}=100$ ) or with gestational diabetes $(\mathrm{N}=100)$ was analyzed for mutations in the $G C K$ gene. All gestational diabetes mellitus patients had good glycemic control maintained by diet alone and no complications during pregnancy. Mutations were detected by single-strand conformation polymorphism and DNA sequencing. Thirteen of the 200 subjects had GCK gene
\end{abstract}


mutations. The mutations detected were in intron 3 (c.43331A $>\mathrm{G}$, new), intron 6 (c.47702T $>$ C, rs2268574), intron 9 (c.48935C $>$ T, rs2908274), and exon 10 (c.49620G $>$ A, rs13306388). None of these $G C K$ mutations were found to be significantly associated with gestational diabetes mellitus. In summary, we report a low frequency of $G C K$ mutations in a pregnant Brazilian population and describe a new intronic variation (c.43331A $>\mathrm{G}$, intron 3). We conclude that mutations in GCK introns and in non-translatable regions of the $G C K$ gene do not affect glycemic control and are not correlated with gestational diabetes mellitus.

Key words: Gestational diabetes; Glucokinase; GCK; SNPs; Mutations; Genetic susceptibility

\section{INTRODUCTION}

Glucokinase (GCK, HK-IV, HK-D, or ATP:D-hexose 6-phosphotransferase), EC 2.7.1.1 (Printz et al., 1993; Jetton et al., 1994; Matschinsky et al., 2006) was first identified in 1962 in rat liver (Iynedjian, 2009). GCK is a monomeric enzyme with dual function in glucose homeostasis (Matschinsky and Ellerman, 1968). GCK phosphorylates glucose in the C6 hydroxyl group and acts as a D-glucose sensor for insulin release in pancreatic beta cells (Matschinsky, 2009).

The affinity of glucokinase toward glucose $\left(K_{\mathrm{m}}, 5-7 \mathrm{mM}\right)$ is about 20 times lower than that for other hexokinases $\left(K_{\mathrm{m}}, 20-130 \mu \mathrm{M}\right)$ and is not inhibited by D-glucose-6-phosphate like the other hexokinase isoforms I, II, and III (Ruzzo et al., 1998).

In the nucleus of hepatocytes and pancreatic beta cells, GCK is bound to the glucokinase regulatory protein (GCKRP; $68 \mathrm{kDa}$ ) when blood glucose is in physiological concentrations $(5-7 \mathrm{mM})$. Under this condition, GCK is in the super-open form and inactive. As the glucose levels increase in the blood and pancreatic beta cells, GCK is released from GCKRP and changes to the closed active form. In the active form, GCK promotes insulin release from beta cells, stimulating glucose phosphorylation (de la Iglesia et al., 1999; Arden et al., 2004).

The human GCK gene is located in the short arm of chromosome 7 (7p15.3-p15.1); it encodes a protein with 465 amino acids (Printz et al., 1993; Gloyn, 2003; Tinto et al., 2008). This gene is about $52 \mathrm{~kb}$ long and has 10 exons according to the reference sequence on NCBI (NG_008847.1). Some authors report that the $G C K$ gene might have 12 exons when all mature RNA transcript possibilities are considered (Jetton et al., 1994; Ellard et al., 2000; Gloyn, 2003; Tinto et al., 2008). GCK exon 1 could be described as exon 1a (pancreatic-controlled promoter) and exons $1 \mathrm{~b} / 1 \mathrm{c}$ as hepatic-controlled promoters (Magnuson and Shelton, 1989; Stoffel et al., 1992).

Gestational diabetes mellitus (GDM) is defined as any degree of glucose intolerance upon first detection or recognition during pregnancy (American Diabetes Association, 2011). This condition increases the risk for pregnant mothers and fetuses for gestational complications (Riskin-Mashiah et al., 2009). GCK gene polymorphisms are associated with monogenic diabetes maturity-onset diabetes of the young type 2 (MODY-2) and is the determinant of 5\% of all cases of GDM in Caucasian populations (Ellard et al., 2000; Gloyn, 2003). Between 1992 and 2009, more than 600 GCK gene mutations were described in different populations (Osbak et al., 2009). GCK heterozygous mutations that reduce enzyme activity lead to MODY2 diabetes, whereas homozygous mutations causing a complete loss of enzyme activity result 
in a rare and dangerous type of diabetes known as permanent neonatal diabetes mellitus, in which affected patients have very low birth weight, intrauterine growth retardation, and severe hyperglycemia (Gloyn, 2003; Greeley et al., 2010; Rubio-Cabezas et al., 2011).

In a European population, the $G C K$ gene promoter polymorphism $-30 \mathrm{G}>\mathrm{A}$ was found to be associated with increased fasting glucose (Rose et al., 2005). This polymorphism was also associated with high levels of glycated hemoglobin and fasting plasma glucose (Rose et al., 2005; Weedon et al., 2005; Santos et al., 2010b).

The aim of this study was to screen mutations in the coding and flanking regions of the $G C K$ gene of pregnant subjects of a Brazilian population with or without gestational diabetes.

\section{MATERIAL AND METHODS}

\section{Subjects}

A sample of 200 pregnant women was classified as healthy (control, $\mathrm{N}=100$ ) or having gestational diabetes (GDM, $\mathrm{N}=100$ ) according to American Diabetes Association criteria (American Diabetes Association, 2010). Clinical and anthropometric data were obtained from all patients. The study was approved by the University's Human Research Ethics Committee.

\section{DNA extraction}

Genomic DNA was obtained from the peripheral blood leukocytes (buffy coat) by the salting-out method (Lahiri and Nurberger, 1991). DNA samples with $\mathrm{A}_{260 / 280}$ ratio between 1.6 and 1.9 were used, and the concentrations of all samples were normalized to $100 \mu \mathrm{g} / \mathrm{mL}$.

\section{Polymerase chain reaction (PCR)}

The GenBank database sequence (NG_008847.1) of the pancreatic glucokinase isoform was used for designing the primers. Primers for amplifying the exons and non-coding exon boundaries 2, $5+6$ (conjugated), 8 , and 9 of the $G C K$ gene have already been described (Tinto et al., 2008). The other primers were designed and analyzed in silico by using the tools Primer3Plus and Blastn. Primer sequences and their characteristics are shown in Table 1.

PCR was performed in a volume of $20 \mu \mathrm{L}$, with a final content of 20-100 ng DNA template, $10 \mathrm{pM}$ each primer, $1.5 \mathrm{mM} \mathrm{MgCl}, 0.2 \mathrm{mM}$ dNTP, $1 \mathrm{X}$ Taq buffer (75 mM Tris-HCl, $\mathrm{pH} 8.8$, $20 \mathrm{mM}\left(\mathrm{NH}_{4}\right) \mathrm{SO}_{4}, 0.01 \%$ Tween 20 ), and $1.0 \mathrm{U}$ Taq DNA polymerase (Fermentas). The reaction cycle included $94^{\circ} \mathrm{C}$ for $60 \mathrm{~s}, 30-35$ cycles of $94^{\circ} \mathrm{C}$ for $30 \mathrm{~s}$, melting temperature for $30 \mathrm{~s}$ (see Table 1), extension $\left(72^{\circ} \mathrm{C}\right)$ for $30 \mathrm{~s}$, and an additional $10 \mathrm{~min}$ at $72^{\circ} \mathrm{C}$ for final extension.

PCR products were verified by $1.5 \%$ agarose gel electrophoresis in $1 \mathrm{X}$ TBE buffer.

\section{PCR-single-strand conformation polymorphism (SSCP)}

SSCP was performed as described previously (Souza et al., 2005). Briefly, $5 \mu \mathrm{L}$ PCR product was added to $10 \mu \mathrm{L}$ formamide loading solution (95\% formamide; $2 \mathrm{mM}$ ethylenediaminetetraacetic acid (EDTA); $0.05 \%$ bromophenol blue, and $0.05 \%$ xylene cyanol) and heated at $98^{\circ} \mathrm{C}$ for $10 \mathrm{~min}$. The mixture was immediately cooled on ice and subjected to polyacrylamide 


\section{Table 1. Primers and PCR-SSCP conditions used.}

\begin{tabular}{|c|c|c|c|c|c|}
\hline \multirow{2}{*}{$\begin{array}{l}\text { GCK } \\
\text { Exons/Amplicons/Primers }\end{array}$} & \multirow[t]{2}{*}{ Bases (bp, $\left.5^{\prime} \rightarrow 3^{\prime}\right)$} & \multirow[t]{2}{*}{$\operatorname{Tm}\left({ }^{\circ} \mathrm{C}\right)$} & \multicolumn{3}{|c|}{ PCR-SSCP conditions** } \\
\hline & & & Gel (\%) & Volts & Time (h) \\
\hline Exon 1 & 515 & & & & \\
\hline Amplicon GCKE1A1 & 337 & & & & \\
\hline GCKE1F1 (20 bp) & 5'-ggtcaccatgacaaccacag-3' & 59.8 & 12 & 300 & 3.5 \\
\hline GCKE1R1 (20 bp) & 5'-ttctggaccettcctcactg-3' & 60.2 & & & \\
\hline Amplicon GCKE1A2 & 337 & & & & \\
\hline GCKE1F2 (18 bp) & 5'-cctgcctggagaacatcc-3' & 59.1 & 12 & 300 & 3.5 \\
\hline GCKE1R2 (19 bp) & 5'-gcaaacactcccagaatgc-3' & 59.2 & & & \\
\hline Amplicon GCKE1A3 & 233 & & & & \\
\hline GCKE1F3 (22 bp) & 5'-gccttggatatttccacttcag-3' & 60.0 & 12 & 300 & 3.5 \\
\hline GCKE1R3 (20 bp) & 5'-cettctcaaagagcctgtgc-3' & 60.1 & & & \\
\hline Exon 2 & 163 & & & & \\
\hline Amplicon GCKE2* & 290 & & & & \\
\hline GCKE2F1 (20 bp) & 5'-tgcagatgcctggtgacagc-3' & 66.0 & 10 & 190 & 3.5 \\
\hline GCKE2R1 (20 bp) & 5'-cacagctgettctggatgag-3' & 59.7 & & & \\
\hline Exon 3 & 155 & & & & \\
\hline Amplicon GCKE3 & 242 & & & & \\
\hline GCKE3F1 (22 bp) & 5'-tgaggctgacacacttctctct-3' & 59.3 & 10 & 190 & 3.0 \\
\hline GCKE3R1 (18 bp) & 5'-ggccetgagatcctgcat-3' & 61.2 & & & \\
\hline Exon 4 & 120 & & & & \\
\hline Amplicon GCKE4 & 251 & & & & \\
\hline GCKE4F1 (20 bp) & 5'-gtccctgaggaatagcttgg-3' & 65.9 & 10 & 190 & 3.5 \\
\hline GCKE4R1 (20 bp) & $5^{\prime}$-cccctcatctgecttctg- $3^{\prime}$ & 60.5 & & & \\
\hline Exon 5 and 6 & 96 and 100 & & & & \\
\hline Amplicon GCKE5e6* & 505 & & & & \\
\hline GCKE5e6F1 (20 bp) & 5'-tctgagcctgtttcctcagc-3' & 60.7 & 10 & 190 & 5.0 \\
\hline GCKE5e6R1 (20 bp) & $5^{\prime}$-ggecettgaagcetgttgta- $3^{\prime}$ & 62.4 & & & \\
\hline Exon 7 & 184 & & & & \\
\hline Amplicon GCKE7 & 286 & & & & \\
\hline GCKE7F1 (20 bp) & 5'-agtgcagctctcgctgacag-3' & 62.1 & 10 & 190 & 4.0 \\
\hline GCKE7R1 (20 bp) & 5'-catctgccgctgcaccagag-3' & 67.8 & & & \\
\hline Exon 8 & 156 & & & & \\
\hline Amplicon GCKE8* & 400 & & & & \\
\hline GCKE8F1 (20 bp) & 5'-tggctcattaacgagggaaa-3' & 60.6 & 10 & 210 & 5.0 \\
\hline GCKE8R1 (20 bp) & 5'-ctgagaccaagtctgcagtg-3' & 57.1 & & & \\
\hline Exon 9 & 234 & & & & \\
\hline Amplicon GCKE9* & 411 & & & & \\
\hline GCKE9F1 (19 bp) & $5^{\prime}$-cctccctggagaacgagag-3' & 63.5 & 9 & 300 & 4.5 \\
\hline GCKE9R1 (20 bp) & 5'-aatcttggagcttgggaacc-3' & 60.4 & & & \\
\hline Exon 10 & 1010 & & & & \\
\hline Amplicon GCKE10A1 & 347 & & & & \\
\hline GCKE10F1 (20 bp) & 5'-cagccetgcttctcttctgc-3' & 62.7 & 10 & 300 & 2.0 \\
\hline GCKE10R1 (21 bp) & 5 -ccgaaaactgagggaagagg-3' & 62.3 & & & \\
\hline Amplicon GCKE10A2 & 278 & & & & \\
\hline GCKE10F2 (18 bp) & 5'-cataccgctggggaacag-3' & 60.1 & 13 & 300 & 2.5 \\
\hline GCKE10R2 (19 bp) & 5'-cccacacaggatgagttcc- 3 ' & 58.9 & & & \\
\hline Amplicon GCKE10A3 & 289 & & & & \\
\hline GCKE10F3 (20 bp) & 5'-atcctgctgtggcctcactt-3' & 62.2 & 13 & 300 & 3.5 \\
\hline GCKE10R3 (21 bp) & 5'-ctctgtctettgcacetgctg-3' & 61.3 & & & \\
\hline Amplicon GCKE10A4 & 299 & & & & \\
\hline GCKE10F4 (21 bp) & 5'-gcttgtgattctgggatggac-3' & 61.8 & 9 & 300 & 2.5 \\
\hline GCKE10R4 (21 bp) & 5'-cccacagtcctaatgcacaga-3' & 61.1 & & & \\
\hline
\end{tabular}

*Primers described by Tinto et al. (2008). **PCR-SSCP conditions, polyacrylamide (29:1) gel concentration (\%) for each amplicon, electrophoresis voltage and run time for BioRad TetraCell (100 x 100-mm plates). Tm = melting temperature $\left({ }^{\circ} \mathrm{C}\right)$.

gel electrophoresis. Gels were prepared in $33 \mathrm{mM}$ Tris-HCl, $\mathrm{pH} 3.66$ (Table 1). All gels were run with $1 \mathrm{X}$ TBE buffer ( $89 \mathrm{mM}$ Tris base; $89 \mathrm{mM}$ boric acid, and $2 \mathrm{mM}$ EDTA, $\mathrm{pH} 8.3$ ). Gels were stained with ethidium bromide and visualized under UV (302 nm) light (UVP System). 


\section{DNA sequencing}

All variants were identified by PCR-SSCP, and about $20 \%$ of all the subjects were sequenced (ET terminator reagent - GE Healthcare; ABI 377 Applied Biosystems) according to manufacturer instructions.

The sequences were compared with the GenBank NG_008847.1. The electropherograms were analyzed by BioEdit v7.0.8.0 and CodonCode Aligner v3.7.1 softwares.

\section{Biochemical markers}

Biochemical parameters such as fasting glucose, lipid profile (total cholesterol, highdensity lipoprotein (HDL) cholesterol, low-density lipoprotein (LDL) cholesterol, and triglycerides), urea, creatinine, and uric acid were quantified using an Architect Ci 8200 automated system (Abbott Diagnostics) and reagents, calibrators, and controls from the equipment manufacturer. Glycosylated hemoglobin $(\mathrm{HbA1C})$ was measured in diabetic pregnant women by using high-performance liquid chromatography equipped with a cation exchange column (Varian II, Biorad).

\section{Statistical analysis}

Continuous variables with normal distribution were compared with the Student $t$-test for independent variables. Triglyceride levels were logarithmically transformed before analysis. The Fisher two-tailed exact test was used to compare categorical variables. Statistical analyses were performed using the Statistica for Windows version 8.0 software (StatSoft Inc., Tulsa). P value lower than $0.05(\mathrm{P}<0.05)$ was considered to be significant.

\section{RESULTS}

The characteristics of the subjects are shown in Table 2.

\begin{tabular}{lccc}
\multicolumn{2}{c}{ Table 2. Clinical characteristics and biomarker concentrations for the studied groups. } & \\
\hline Characteristics & $\begin{array}{c}\text { Control group } \\
(\mathrm{N}=100)\end{array}$ & $\begin{array}{c}\text { GDM group } \\
(\mathrm{N}=100)\end{array}$ & $\mathrm{P}$ \\
\hline Age (years) & $24.9 \pm 6.2$ & $31.7 \pm 6.3$ & $<0.001$ \\
Euro-/Afro-Brazilians (\%) & $95 / 5$ & $90 / 10$ & 0.18 \\
Body mass index $\left(\mathrm{kg} / \mathrm{m}^{2}\right)$ & $25.2 \pm 4.2$ & $33.5 \pm 6.3$ & $<0.001$ \\
Family history for diabetes $(\%)$ & 5 & 69 & $<0.001^{*}$ \\
Hypertension $(\%)$ & 1.3 & $5.8 \pm 1.2$ & $<0.001^{*}$ \\
Total cholesterol $(\mathrm{mM})$ & $5.0 \pm 1.2$ & $1.4 \pm 0.3$ & $<0.001$ \\
HDL cholesterol $(\mathrm{mM})$ & $1.0 \pm 0.2$ & $3.3 \pm 1.1$ & $<.001$ \\
LDL cholesterol $(\mathrm{mM})$ & $3.4 \pm 1.0$ & $2.5 \pm 0.8$ & $<.0 .001^{* *}$ \\
Triglycerides $(\mathrm{mM})$ & $1.3 \pm 0.5$ & $67.0 \pm 7.9$ & $<0.001$ \\
Creatinine $(\mu \mathrm{M})$ & $74.2 \pm 8.0$ & $5.2 \pm 1.1$ & $<0.001$ \\
Fasting glucose $(\mathrm{mM})$ & $4.5 \pm 0.4$ & $5.6 \pm 0.8$ & - \\
HbA1C $(\%)$ & - & & \\
\hline
\end{tabular}

Values are reported as means $\pm \mathrm{SD}$ or $\% . \mathrm{P}$ value $=t$-test for independent variables. $*$ Fisher two-tailed exact test. $* *$ Calculated for log-transformed values. GDM $=$ gestational diabetes mellitus. 
Diabetic patients were older, heavier, and had a high frequency of hypertension than the controls. No significant ethnic differences were observed between the Euro-Brazilian and Afro-Brazilian $(\mathrm{P}=0.18)$ populations.

Total cholesterol, HDL cholesterol, LDL cholesterol, and triglycerides were higher in the GDM group, but the LDL cholesterol levels showed no significant differences between the groups studied.

Fasting glucose levels were statistically higher and glycated hemoglobin concentrations were within the reference range (4.0-6.0\%) in the GDM group.

All GDM patients showed a good glycemic control maintained by diet alone and did not show complications during pregnancy.

Mutations were detected in 13 subjects $(6.5 \%$ of total). All variations were found in the intronic (introns 3, 6, and 9 and 10) regions (Table 3).

Table 3. Mutations detected in the $G C K$ gene in the studied population.

\begin{tabular}{|c|c|c|c|c|}
\hline \multirow[t]{2}{*}{ Mutation characteristics } & \multicolumn{4}{|c|}{ Glucokinase gene region } \\
\hline & Intron 3 & Intron 6 & Intron 9 & Exon 10 \\
\hline $\begin{array}{l}\text { Chromosome position } \\
\text { dbSNP }^{2}\end{array}$ & $\begin{array}{c}\text { c. } 43331 \mathrm{~A}>\mathrm{G} \\
-\end{array}$ & $\begin{array}{l}\text { c. } 47702 \mathrm{~T}>\mathrm{C} \\
\mathrm{rs} 2268574\end{array}$ & $\begin{array}{l}\text { c. } 48935 \mathrm{C}>\mathrm{T} \\
\mathrm{rs} 2908274\end{array}$ & $\begin{array}{l}\text { c. } 49620 \mathrm{G}>\mathrm{A} \\
\text { rs } 13306388\end{array}$ \\
\hline Presence in control/GDM & $1 / 0$ & $10 / 0$ & $1 / 1$ & $0 / 2$ \\
\hline Genotype $11^{3}$ & 199 & 190 & 198 & 198 \\
\hline Genotype $12^{3}$ & 1 & 7 & 1 & 0 \\
\hline Genotype $22^{3}$ & 0 & 3 & 1 & 2 \\
\hline Rare allele frequency $(\%)$ & G-allele 0.3 & C-allele 3.3 & T-allele 0.8 & A-allele 1.0 \\
\hline $95 \% \mathrm{CI}$ & $(0-1)$ & $(2-5)$ & $(0-2)$ & $(0-2)$ \\
\hline
\end{tabular}

${ }^{1}$ Chromosome position $=$ SNP notation according NCBI NG_008847.1. ${ }^{2} \mathrm{dbSNP}=$ Data Base Reference SNP (http:// www.ncbi.nlm.nih.gov/projects/SNP/). ${ }^{3}$ Genotypes 11,12 and 22 were usual homozygous, heterozygous and rare homozygous, respectively. $95 \% \mathrm{CI}=95 \%$ confidence interval.

The mutations c.47702T $>$ C, c.48935C $>$ T, and c.49620G $>$ A were not in Hardy-Weinberg equilibrium $(\mathrm{HWE})(\mathrm{P}<0.001)$. The mutation detected in intron $3, \mathrm{c} .43331 \mathrm{~A}>\mathrm{G}$, was in HWE $(\mathrm{P}=0.97)$.

\section{DISCUSSION}

Gestational diabetes has a frequency of about 7\% (Schmidt et al., 2000) in the Brazilian population, and $5-7 \%$ of all the cases were found to have a GCK mutation (Ben-Haroush et al., 2004; American Diabetes Association, 2010; Liang et al., 2010). New insights on gestational diabetes suggested that detection of affected subjects is important for determining the pregnancy outcome (Metzger et al., 2008).

Clinical characteristics and biochemical parameters (Table 2) of the studied groups were similar to those reported in other studies (Santos et al., 2010a). GDM patients were usually heavier since overweight is a risk factor associated with this pathology and type 2 diabetes (Rosenberg et al., 2005; Rivero et al., 2008).

The high levels of total cholesterol and triglycerides in GDM patients were observed previously (Meyers-Seifer and Vohr, 1996; Grundy et al., 2006; American Diabetes Association, 2010; Marcinkevage and Narayan, 2011) and are consistent with frequent association of GDM with lipid profile modifications (Knopp et al., 1980). The significantly higher levels of 
HDL cholesterol observed in GDM patients compared to controls was not observed in other studies (Grundy et al., 2006; American Diabetes Association, 2010; Marcinkevage and Narayan, 2011) that reported low HDL cholesterol levels in GDM patients of different populations.

LDL cholesterol levels did not show significant differences between the studied groups, which were also consistent with the findings of other studies, although a reduction in LDL cholesterol fraction associated with GDM has been reported (Metzger et al., 1980; Hollingsworth and Grundy, 1982). Glucose levels and HbA1C from GDM indicate that the patients had good glycemic control.

The subjects also had healthy habits such as balanced meals and physical exercise, factors that increase HDL cholesterol and normalize LDL cholesterol and glycemia. An analysis of the biochemical parameters and clinical characteristics indicated that our GDM group was well controlled and substantially different from those reported in other studies.

In this study, we used PCR-SSCP, first proposed by Orita et al. (1989), under acidic conditions, as described by Souza et al. (2005). For this screening, we used small-size amplicons that allowed a sensitivity of about $90 \%$ with this technique (Hayashi, 1991). Several SSCP conditions were tested, such as addition of glycerol and polyethyleneglycol and adjusting $\mathrm{pH}$ and gel concentrations. The optimized procedure that showed the best mutation identification was obtained with polyacrylamide gels prepared in low $\mathrm{pH}$, as described by Souza and colleagues (2005).

PCR-SSCP detected 13 samples (6.5\%) with different electrophoresis patterns. Sequencing and analysis of these amplicons showed 4 different mutations (Table 3).

All detected mutations are transitions present in intron $3(\mathrm{c} .43331 \mathrm{~A}>\mathrm{G})$, intron 6 (c.44702T $>C$, rs2268574), intron 9 (c.48935C $>$ T, rs2908274), and the non-coding region of exon 10 (c.49620G>A, rs13306388). The mutation detected in intron 3 was the only that was in HWE. The relatively small sample size associated with low frequencies of the mutation could explain the HWE results. The dbSNP database showed a considerably higher frequency $(>50 \%)$ for the rare allele of mutation rs 2268574 in intron 6 than that observed in this study (3.3\%). However, this database does not reflect the findings obtained in population studies, has a small sample size, and is composed of samples of different ethnicities, which could explain the differences observed. No published frequencies were found for the other mutations detected in this study. The rare mutation in intron $3(\mathrm{c} .43331 \mathrm{~A}>\mathrm{G})$ was not described in any database. Overall, the low frequencies of the detected mutations did not show reliable association with GDM.

Ellard et al. (2000) found a high prevalence of GCK gene mutations (80\%) in GDM patients, which could be explained by the selection of a small study group $(\mathrm{N}=15)$ with several criteria that enriched the presence of mutations. Briefly, the criteria were 1) persisting fasting hyperglycemia outside pregnancy, 2) increment in fasting and 2-h plasma glucose, 3) insulin treatment during pregnancy, and 4) history of type 2 diabetes, gestational diabetes, or fasting hyperglycemia. Kousta and colleagues (2001) reported a prevalence of $12 \% G C K$ gene mutations in a multiethnic population; subjects in this study were also selected by criteria similar to those of Ellard et al. (2000).

Both the studies showed mutation prevalence in the $G C K$ gene that was considerably higher than that reported in this study. These differences are probably due to the selection criteria of the GDM patients, since GDM alone was selected based on good glycemic control in this study. 
In summary, in this study, the frequency of $G C K$ mutations in a pregnant Brazilian population has been reported, and a new intronic variation (c.43331A $>\mathrm{G}$, intron 3) for this gene was described. The mutation in introns and non-translatable regions of the $G C K$ gene did not affect glycemic control and was not correlated with the GDM condition in healthy and GDM women.

\section{ACKNOWLEDGMENTS}

We are thankful to Dr. M.G. Yates for reading the manuscript and for the suggestions. $\mathrm{CNPq}$ and Araucaria Foundation supported this project. No potential conflicts of interest relevant to this article were reported.

\section{REFERENCES}

American Diabetes Association (2010). Diagnosis and classification of diabetes mellitus. Diabetes Care 33 (Suppl 1): S62-S69.

American Diabetes Association (2011). Diagnosis and classification of diabetes mellitus. Diabetes Care 34 (Suppl 1): S62-S69.

Arden C, Harbottle A, Baltrusch S, Tiedge M, et al. (2004). Glucokinase is an integral component of the insulin granules in glucose-responsive insulin secretory cells and does not translocate during glucose stimulation. Diabetes 53: 2346-2352.

Ben-Haroush A, Yogev Y and Hod M (2004). Epidemiology of gestational diabetes mellitus and its association with Type 2 diabetes. Diabet. Med. 21: 103-113.

de la Iglesia N, Veiga-da-Cunha M, Van Schaftingen E, Guinovart JJ, et al. (1999). Glucokinase regulatory protein is essential for the proper subcellular localisation of liver glucokinase. FEBS Lett. 456: 332-338.

Ellard S, Beards F, Allen LI, Shepherd M, et al. (2000). A high prevalence of glucokinase mutations in gestational diabetic subjects selected by clinical criteria. Diabetologia 43: 250-253.

Gloyn AL (2003). Glucokinase (GCK) mutations in hyper- and hypoglycemia: maturity-onset diabetes of the young, permanent neonatal diabetes, and hyperinsulinemia of infancy. Hum. Mutat. 22: 353-362.

Greeley SA, Tucker SE, Worrell HI, Skowron KB, et al. (2010). Update in neonatal diabetes. Curr. Opin. Endocrinol. Diabetes Obes. 17: 13-19.

Grundy SM, Cleeman JI, Daniels SR, Donato KA, et al. (2006). Diagnosis and management of the metabolic syndrome: an American Heart Association/National Heart, Lung, and Blood Institute scientific statement. Curr. Opin. Cardiol. 21: 1-6.

Hayashi K (1991). PCR-SSCP: a simple and sensitive method for detection of mutations in the genomic DNA. PCR Methods Appl. 1: 34-38.

Hollingsworth DR and Grundy SM (1982). Pregnancy-associated hypertriglyceridemia in normal and diabetic women. Differences in insulin-dependent, non-insulin-dependent, and gestational diabetes. Diabetes 31: 1092-1097.

Iynedjian PB (2009). Molecular physiology of mammalian glucokinase. Cell Mol. Life Sci. 66: 27-42.

Jetton TL, Liang Y, Pettepher CC, Zimmerman EC, et al. (1994). Analysis of upstream glucokinase promoter activity in transgenic mice and identification of glucokinase in rare neuroendocrine cells in the brain and gut. J. Biol. Chem. 269: 3641-3654.

Knopp RH, Chapman M, Bergelin R, Wahl PW, et al. (1980). Relationships of lipoprotein lipids to mild fasting hyperglycemia and diabetes in pregnancy. Diabetes Care 3: 416-420.

Kousta E, Ellard S, Allen LI, Saker PJ, et al. (2001). Glucokinase mutations in a phenotypically selected multiethnic group of women with a history of gestational diabetes. Diabet. Med. 18: 683-684.

Lahiri DK and Nurnberger JI Jr (1991). A rapid non-enzymatic method for the preparation of HMW DNA from blood for RFLP studies. Nucleic Acids Res. 19: 5444.

Liang Z, Dong M, Cheng Q and Chen D (2010). Gestational diabetes mellitus screening based on the gene chip technique. Diabetes Res. Clin. Pract. 89: 167-173.

Magnuson MA and Shelton KD (1989). An alternate promoter in the glucokinase gene is active in the pancreatic beta cell. J. Biol. Chem. 264: 15936-15942.

Marcinkevage JA and Narayan KM (2011). Gestational diabetes mellitus: taking it to heart. Prim. Care Diabetes 5: 81-88. Matschinsky FM (2009). Assessing the potential of glucokinase activators in diabetes therapy. Nat. Rev. Drug. Discov. 
8: 399-416.

Matschinsky FM and Ellerman JE (1968). Metabolism of glucose in the islets of Langerhans. J. Biol. Chem. 243: 2730-2736.

Matschinsky FM, Magnuson MA, Zelent D, Jetton TL, et al. (2006). The network of glucokinase-expressing cells in glucose homeostasis and the potential of glucokinase activators for diabetes therapy. Diabetes 55: 1-12.

Metzger BE, Phelps RL, Freinkel N and Navickas IA (1980). Effects of gestational diabetes on diurnal profiles of plasma glucose, lipids, and individual amino acids. Diabetes Care 3: 402-409.

Metzger BE, Lowe LP, Dyer AR, Trimble ER, et al. (2008). Hyperglycemia and adverse pregnancy outcomes. N. Engl. J. Med. 358: 1991-2002.

Meyers-Seifer CH and Vohr BR (1996). Lipid levels in former gestational diabetic mothers. Diabetes Care 19: 1351-1356.

Orita M, Iwahana H, Kanazawa H, Hayashi K, et al. (1989). Detection of polymorphisms of human DNA by gel electrophoresis as single-strand conformation polymorphisms. Proc. Natl. Acad. Sci. U. S. A. 86: 2766-2770.

Osbak KK, Colclough K, Saint-Martin C, Beer NL, et al. (2009). Update on mutations in glucokinase (GCK), which cause maturity-onset diabetes of the young, permanent neonatal diabetes, and hyperinsulinemic hypoglycemia. Hum. Mutat. 30: 1512-1526.

Printz RL, Magnuson MA and Granner DK (1993). Mammalian glucokinase. Annu. Rev. Nutr. 13: 463-496.

Riskin-Mashiah S, Younes G, Damti A and Auslender R (2009). First-trimester fasting hyperglycemia and adverse pregnancy outcomes. Diabetes Care 32: 1639-1643.

Rivero K, Portal VL, Vieira M and Behle I (2008). Prevalence of the impaired glucose metabolism and its association with risk factors for coronary artery disease in women with gestational diabetes. Diabetes Res. Clin. Pract. 79: 433-437.

Rose CS, Ek J, Urhammer SA, Glumer C, et al. (2005). A -30G $>$ A polymorphism of the beta-cell-specific glucokinase promoter associates with hyperglycemia in the general population of whites. Diabetes 54: 3026-3031.

Rosenberg TJ, Garbers S, Lipkind H and Chiasson MA (2005). Maternal obesity and diabetes as risk factors for adverse pregnancy outcomes: differences among 4 racial/ethnic groups. Am. J. Public. Health 95: 1545-1551.

Rubio-Cabezas O, Klupa T and Malecki MT (2011). Permanent neonatal diabetes mellitus - the importance of diabetes differential diagnosis in neonates and infants. Eur. J. Clin. Invest. 41: 323-333.

Ruzzo A, Andreoni F and Magnani M (1998). Structure of the human hexokinase type I gene and nucleotide sequence of the 5 ' flanking region. Biochem. J. 331 (Pt 2): 607-613.

Santos IC, Daga DR, Frigeri HR, Rea RR, et al. (2010a). The functional polymorphisms $-429 \mathrm{~T}>\mathrm{C}$ and $-374 \mathrm{~T}>\mathrm{A}$ of the RAGE gene promoter are not associated with gestational diabetes in Euro-Brazilians. Genet. Mol. Res. 9: 1130-1135.

Santos IC, Frigeri HR, Rea RR, Almeida AC, et al. (2010b). The glucokinase gene promoter polymorphism $-30 \mathrm{G}>\mathrm{A}$ (rs1799884) is associated with fasting glucose in healthy pregnant women but not with gestational diabetes. Clin. Chim. Acta 411: 892-893.

Schmidt MI, Matos MC, Reichelt AJ, Forti AC, et al. (2000). Prevalence of gestational diabetes mellitus - do the new WHO criteria make a difference? Brazilian Gestational Diabetes Study Group. Diabet. Med. 17: 376-380.

Souza RL, Mikami LR, Maegawa RO and Chautard-Freire-Maia EA (2005). Four new mutations in the BCHE gene of human butyrylcholinesterase in a Brazilian blood donor sample. Mol. Genet. Metab. 84: 349-353.

Stoffel M, Froguel P, Takeda J, Zouali H, et al. (1992). Human glucokinase gene: isolation, characterization, and identification of two missense mutations linked to early-onset non-insulin-dependent (type 2) diabetes mellitus. Proc. Natl. Acad. Sci. U. S. A. 89: 7698-7702.

Tinto N, Zagari A, Capuano M, De Simone A, et al. (2008). Glucokinase gene mutations: structural and genotypephenotype analyses in MODY children from South Italy. PLoS One 3: e1870.

Weedon MN, Frayling TM, Shields B, Knight B, et al. (2005). Genetic regulation of birth weight and fasting glucose by a common polymorphism in the islet cell promoter of the glucokinase gene. Diabetes 54: 576-581. 